\title{
WEBERIAN SOCIOLOGY AND PORTRAIT OF CONTEMPORARY SUFISM STUDIES
}

\author{
Abdul Kadir Riyadi \\ Universitas Islam Negeri Sunan Ampel Surabaya, Indonesia \\ riyadi.abdulkadir@gmail.com
}

Article history: Received: 11 May 2020; Accepted: 21 October 2020; Published: 30 October 2020

\begin{abstract}
:
Applying Weberian sociology to the study of Islam is a problematic undertaking. This paper highlights the difficulties in reconciling the Western approach to the study of religion and Islam with the principles of objective and unbiased scholarship. Max Weber is considered one of the fathers of modern sociology, yet his major works largely ignore Islam and Muslim society. If he mentions Islam, then only briefly and with a lot of misgivings. Weber's persistent bias towards Islam has generated a lot of consternation in Muslim circles and has given rise to much speculation and debate. Some of Weber's intellectual heirs have tried to fill this gap and included Islam in their research. Although the result is often unbalanced and unsympathetic, his successors have enriched the sociological study of Islam and Sufism. Weber's modern critics have refuted his major hypotheses and introduced a more objective approach to the study of Islam and Sufism. The ongoing dispute between the Weberians and their opponents on the nature of Sufism invites further discussion. This paper is aimed at examining this debate exploring the richness of spiritual Islam as studied by Weberian sociologists and their critics.
\end{abstract}

Keywords: Countersociology; Eurocentrism; Sufism; Weberian Sociology

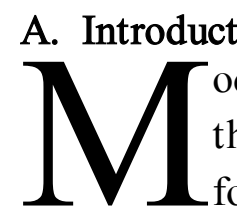

\section{ction}

odern sociology is strongly influenced by the Weberian school. Although the pre-modern Muslim historian Ibn Khaldun ${ }^{1}$ is considered the historical founder of sociology, it was the German historian and political economist Max Weber (1864-1920) who established sociology as a modern social science. His theories not only dominate the early economic and social sciences, but also the study of religion and mysticism. Generations of scholars have studied Weber's social

1 Ibn Khaldun (1332-1406) is a prominent figure in the history of Muslim civilization. His social science theory is based on the concept of clan solidarity ('as abiya) and the rise and fall of civilization as elaborated in his monumental work, the Prolegomena (al-Muqaddima). Ibn Khaldun's thought laid the foundations to the science of sociology long before the emergence of modern sociology in the West. Mehmet Soyer, "Examining the Origins of Sociology: Continuities and Divergences Between Ibn Khaldun, Giambattista Vico, August Comte, Ludwig Gumplowicz, and Emile Durkheim," Master's thesis, University of North Texas, 2010. 
theories, modified them, and applied them to their own research. In the social study of religion, Weber's own contributions and those who continued in his footsteps clearly dominate the scholarly discourse. It is, therefore, no surprise that even Islamic sociology, as devised by contemporary Muslim scholars, is heavily influenced by Weberian scholars. Their theories are still being debated today, even in the study of Islamic sociology. It can even be argued that there would be no study of Islamic sociology if not for Weber and his modern theoretical groundwork. In Muslim academic circles, however, Weber's strongly biased view of Islam makes his thought highly controversial, irrespective of his authority in the field.

Furthermore, Islamic sociology is a new discipline and still immature in its development. It has slowly emerged as a combination of Islamic studies and social sciences, and its wide scope of study attracts a growing number of scholars and students worldwide. The discourse offered in Islamic sociology is also very diverse, as it is not limited to Muslim scholarship and research. The alternative term sociology of Islam reflects more closely the Weberian approach, but it is Muslim and non-Muslim scholars who are equally involved in the development of this science. The most recent and most noteworthy contribution has been made by Armando Salvatore, a professor of global religious studies at McGill University. ${ }^{2}$ Considering the lack of comprehensive studies in this new area of research, his work has prepared the ground for future studies. This confirms the observation made by Turner that Islamic sociology is developing rather slowly. ${ }^{3}$ However, this does not necessarily mean that sociological studies of religion and its various dimensions are suspended or restricted. $\mathrm{Sufism}^{4}$ or the Islamic spiritual tradition constitutes one of the dimensions of Islam that has merited much attention from sociologists. Since the early $20^{\text {th }}$ century, Western scholars have competed in interpreting mystical phenomena sociologically. The Weberian paradigm is indeed very useful in this regard, and many scholars have learned to look for provisions from Weberian theory when studying Sufism.

Herein lies the importance of tracing the development of contemporary Sufism studies within the framework of Weberian sociology. Such an effort will help us better understand how Sufism can be studied from a sociological perspective. Since sound scientific research must be based on tested and tried rational principles, the sociological approach to Sufism seems commendable. Moreover, it is expected to initiate a fresh discourse in this area. This study is divided into three parts: i) overview of Weber's sociology of religion; ii) Weberian interpretation of Sufism; and iii) current

2 Armando Salvatore, The Sociology of Islam: Knowledge, Power and Civility (USA: WileyBlackwell, 2016), 2.

3 Bryan S. Turner, "Revisiting Weber and Islam," The British Journal of Sociology 61, no. 1 (2010): 161-166, https://doi.org/10.1111/j.1468-4446.2009.01285.x.

4 Sufism refers to Islamic mysticism that is the belief and practices that bring the believers closer to Allah. The equivalent Arabic term is tasawwuf. Shahida Bilqies, "Understanding the Concept of Islamic Sufism," Journal of Education \& Social Policy 1, no. 1 (2014): 55-72, http://jespnet.com/journal/index/2130. 
criticism of Weber's theory on religion and Sufism. Although Weber was not sympathetic to Islam, this study will try to be as objective as possible in studying his general ideas on religion and mysticism.

\section{B. Max Weber and His Complicated Legacy}

One hundred years after the death of Max Weber in 1920, the study of sociology that he founded continues to be the object of much discussion and debate. His ideas have remained controversial and have never been completely accepted or rejected. The Weberian school has much to offer to the discourse, and its contributions must be duly considered when studying sociology of religion. However, Weber's original thought has been modified, adapted, and expanded over time. The European society that Weber observed and studied in his days is not the society that we observe and study today. Fundamental changes in the aspects of structure, tradition, mindset, relationship patterns, and dynamics determine the framework that we study today. Likewise, the characteristics of Asian society have also changed considerably. This also means that the social conditions surrounding the world's religions are very different from the past.

Yet, studying Weber's ideas has not become irrelevant. According to Turner, Weber is still an "essentially contested author," even today. ${ }^{5}$ In terms of the sophistication of his ideas, it is safe to say that they have largely remained unparalleled. He is counted among the eminent scholars and thinkers whose theories have colored the development of contemporary social sciences, in the West and elsewhere. Without his contribution, there might not even be the science of sociology at all. Thus, we can still derive much benefit from reading his work, even though the complexity of his thought and the outdated structure of his material can be quite daunting to some.

Weber is an eminent figure in sociology who has inspired many scholars, whether positively or negatively. He authored numerous works most of which are written in German. The German edition of Economy and Society: An Outline of Interpretive Sociology was first published in $1920^{6}$ and later translated and published in English in 1978. ${ }^{7}$ Its first launch was welcomed enthusiastically by other sociologists such as Arthur Stinchcombe, Reinhard Bendix, and Guenther Roth. In their eyes, this work was "the greatest sociological text of this century." His other important work relevant to our discussion is From Max Weber: Essays in Sociology 8 , a collection of Weber's writings compiled and translated into English. Turner, one of Weber's most

\footnotetext{
Bryan S. Turner, “Max Weber: From History to Modernity (London: Routledge, 1992).

6 Max Weber, Wirtschaft und Gesellschaft - Grundriß der verstehenden Soziologie, (Tübingen: Mohr, 1980).

7 Max Weber, Economy and Society: An Outline of Interpretive Sociology, edt. Guenther Roth, Claus Wittich, (New York: Bedminster Press, 1968).

8 Max Weber, From Max Weber, Essays in Sociology, edt. trans. Hans Heinrich Gerth \& Charles Wright Mills, (England: Routledge, 1991).
} 
accomplished successors, wrote the preface to this edition. In these essays, Weber discusses various issues such as sciences and politics, power, and social structure that are part of the historical process of change. He also awards separate attention to religion. In his view, which was characteristic of the $19^{\text {th }}$ and early $20^{\text {th }}$ century, religion has a role in the course of human history. In his 'typology of asceticism and mysticism, he argues that asceticism is an active concept, while mysticism is a passive concept. The former is valuable in the context of creating the spirit of capitalism, while the latter inhibits such a spirit.

Another important work of his is The Protestant Ethic and the Spirit of Capitalism. ${ }^{9}$ The derived moral code emphasized the principles of hard work, life discipline, and organizing human life to serve the religion and God. Weber acknowledged the important role religion plays in society. He did not agree with his more extreme contemporaries who categorically rejected any notion of religion and denied the existence of God, such as Karl Marx in his social theory. Weber himself rejected Marxism, especially the principle of dialectical materialism which was inherently atheistic. ${ }^{10}$ Weber was more inclined to a moral approach. For him, 'moral goodness' as reflected in Protestant ethics was the best way to progress and change. Its essence is the ethos of hard work at the physical level. It rejects the notion of predestination, where individual fate is determined by God and cannot be altered. Meanwhile, he regarded spirituality as a positive factor for society as well, as it contained teachings to overcome anxiety and reach salvation through good deeds. These factors were responsible for the birth of a capitalistic economy, industrialism, and even modernity.

According to Parsons, ${ }^{11}$ Weber's main contribution to Protestant ethics lies in his ability to explain how religious and cultural values influence individual and group behavior. Where Marx saw religion as a tool of oppression, Weber saw an integral part of human culture. However, the aspects of revelation and sacredness are missing in his context. Religion is understood as a human construct, and the existence and role of God are entirely absent. There is no true faith or fixed moral code in the real sense. What exists is a moral order established and maintained by society as the product of social consensus that is constantly developing. Thus, morality is strictly temporary and has lost its element of universality.

The scope of Weber's sociology is very broad. His views on religion, for instance, are rather eclectic and inconsistent. The challenge in studying Weber's

9 Max Weber, The Protestant Ethics and the Spirit of Capitalism, (New York: Routledge, 2001).

10 Through this theory, Marx wanted to emphasize that change can only occur through the process of class struggle. Every society is comprised of opposing forces that compete for power and domination. A dialectical mechanism of progress necessitates collision or contention, whereas dialogue leads to alliance. To achieve a change, according to Marx, it requires a clash between those who have power and access to economic resources and those who are deprived of them in the capitalist system.

11 Talcott Parsons, Essays in Sociological Theory, (Glencoe, III: Free Press, 1958). 
thought is knowing how to position a specific religion within this framework and interpret it accordingly, for instance, as applied to Sufism. How the study of Sufism based on Weber's sociological theory can be carried out is a complex challenge, because there are some variables that seem to be difficult to reconcile. To overcome this problem, the most possible strategy is to examine Weber's ideas on the sociology of religion and apply them specifically to the sociology of Islam. From this vantage point, we are then able to discuss the debates that have arisen in the context of the study of Sufism today.

\section{Religion in Weber's Sociology}

Weber viewed religion as a belief in supernatural powers. ${ }^{12}$ In other words, something can be called a religion or not depending on the presence or absence of such belief. Functionalism ${ }^{13}$ offers another useful definition. Emile Durkheim (1858-1917) and Talcott Parsons (1902-1979), for example, understood religion from the aspect of its social and psychological functions. They proposed that religion is believed to have certain functions in society such as creating unity, harmony, and common awareness. Meanwhile, structuralism ${ }^{14}$ supposes that religion depends on the process and who has the authority to determine that a certain belief or faith can be called a religion. Comparing both views, Weber's definition is broader and includes the term 'belief.' His understanding of religion contains a normative sense that should be present in religion. On the other hand, his understanding of religion does not have much sociological nuance because it largely ignores the social aspect of religion.

Several of Weber's works dealt with the role of religion in society: i) Protestantism, ii) Confucianism and Taoism, iii) Hinduism and Buddhism, and iv) ancient Judaism. Interestingly, however, he did not dedicate a separate study to the religion of Islam. In these works, Weber examined the problem of social action in an attempt to understand the drive behind the action. What is meant by social action are not facts found on the ground but the phenomenon of the relationship between one action and another. In other words, his sociology of religion intended to reveal historical narratives and the acts of individuals or communities as expressions of their religiosity. In Berger's opinion, Weber put great emphasis on the problem of elective affinities (Wahlverwandtschaften), a moment in which ideas and social processes seek

12 W. G. Runciman, "The Sociological Explanation of 'Religious' Beliefs," European Journal of Sociology 10, no. 2 (November 28, 1969): 149-91, https://doi.org/10.1017/S0003975600001806.

13 Structuralism is the school of thought that human behavior must be understood in the context of the social system or structure in which they exist. Encyclopedia.com, "Functionalism and Structuralism' Encyclopedia of Sociology," February 7, 2021, https://www.encyclopedia.com/socialsciences/encyclopedias-almanacs-transcripts-and-maps/functionalism-and-structuralism.

14 Functionalism asserts that a society functions like a biological organism that grows, and as a consequence, its parts can be examined with respect to how they operate (or function) to maintain the viability of the body social as it grows and develops. Encyclopedia.com, "Functionalism and Structuralism' Encyclopedia of Sociology," February 7, 2021, https://www.encyclopedia.com/socialsciences/encyclopedias-almanacs-transcripts-and-maps/functionalism-and-structuralism.

Teosofia: Indonesian Journal of Islamic Mysticism, Vol. 9, No. 2, 2020 
and complement each other. ${ }^{15}$ This is meant by interpretive sociology (verstehende Soziologie) meaning sociology that relies on the reader's ability to interpret reality. Thus, religion is understood as a social process, not an idea. The idea comes from the interpreter; however, as an object, religion is ultimately a construct of the subject. Thus, it follows that religion is a human creation. Weber rejects the concept of prophethood because it is part of the past and not the present. ${ }^{16}$

Weber approached religion from the viewpoint of an observer, not a participant. It is not surprising, therefore, that his observations on religion are replete with negative sentiments. In his theory of modern economics, he viewed religion as a mere tool to achieve economic prosperity. He observed that there was a positive relationship between religion and economics but limited its role to serve the economy. $\mathrm{He}$ described the modern capitalist economy as the result of ordered and efficient rational processes in terms of financing, taking care of labor, and taking advantage of the free market. All these processes are carried out by those who are work-oriented, disciplined, and endowed with a strong work ethic. He then concluded that only a dynamic religion like Protestantism can provide the foundation for the development of a modern economy. In the political context, the state as a political symbol has a monopoly of power, while a religious leader, as a religious symbol, has a monopoly on truth. Both often work together to achieve their mission. The state uses religion to seek legitimacy for its power, while religion seeks help from the state to fund and protect it. Their capacity for oppression is formidable when religion and state work together because their power seems sacred. In consequence, opposing them is not only wrong but sinful.

Weber also discussed the concept of theodicy, God's justice, and human freedom The concept of theodicy revolves around the question of the reason for good and evil, misery and happiness in the world. This is an old question that has been widely discussed in Islamic thought, especially by the Mu'tazilite. In answer to the problem of theodicy, Weber argues that Protestant ethics have social and even economic relevance. Religion offers the concept of salvation; a concept that becomes the foundation to have hope and motivation in life. As a result, people compete to achieve the best possible outcome, including creating a developed social and economic order. Weber thus concludes that capitalism, industrialism, and modernity were born from this process.

Despite its powerful logic, Weber's social theory is not universally accepted. Many consider his theory too idealistic and not representative of a social reality that is often far more complex and far less predictable. Furthermore, Weber did not believe that religions other than Protestantism, especially Islam, have the same capacity to bring about progress. However, by denying Islam the dynamic force to initiate a socio-

15 Peter L. Berger, "Charisma and Religious Innovation: The Social Location of Israelite Prophecy," American Sociological Review 28, no. 6 (1963): 950, https://doi.org/10.2307/2090313.

16 Weber, From Max Weber: Essays in Sociology... 152. 
economic revolution, Weber denied (or chose willingly to ignore) an obvious historical fact. Further, civilization is not only the product of one religion but the result of the collective effort of all communities and a continuation of the past, building on the knowledge and experience of previous civilizations. Weber's historical logic does not work here. He seems to forget that nations build on the achievements of other nations before them and that human progress is shared. Turner thus correctly concludes that "Weber's ideas about Asian religions are a form of Western Orientalism." 17 Weberian orientalism is not much different from others, which tends to 'oppress objects,' to borrow Edward Said's term. The objects of Islam, and Muslim societies in extension, are both target and victim, with no voice or agency. Weber saw Islam primarily as a religion of slavery, polygamy, and warfare. ${ }^{18}$

According to Weber, the basic nature of Islam is patrimonial and feudal. $\mathrm{He}$ understood the system of Islamic patrimonialism as the result of jiha $\bar{d}$ and aggressive territorial expansion. Here, the idea of salvation that originally existed in Islam is diminished or even non-existent. It is only found in Protestantism and is the sole origin of the spirit of capitalism. The institutions that promote the growth of capitalist preconditions, such as rational law, free markets, autonomous cities, and the bourgeoisie, are entirely absent in Weber's portrayal of Muslim society. In other words, he saw Islam as a worldly religion with a strong political component. He concluded that "the emphasis on holy war and the promise that soldiers will get to heaven if they die on the battlefield has made Islam ignore the concept of ethical salvation."19

Paradoxically, Weber also argued that Islamic feudalism was born due to the strong influence of mysticism. This passive manner, in contrast to dynamic asceticism, triggered the birth of a passive mentality and acceptance of the status quo. Weber viewed Islamic feudalism as the direct impact of the Prophet's charismatic authority on his followers. This explanation seems a bit perplexing, considering that he viewed charisma as a positive and dynamic force to bring about social change in society. Turner tries to explain this contradiction by explaining that charisma is ideal for traditional societies. In a rational society, such as the modern West, charismatic inspiration is replaced by science and bureaucratic organization. It follows that charisma and the notion of mystery contained in mysticism are useless for realizing modernity. ${ }^{20}$

However, Turner relates Weber's authoritarianism with modern Muslim revivalism, as represented by Jamal al-Din al-Afghani (1838-1897), Muhammad

17 Turner, "Revisiting Weber and Islam," ... 161-166.

18 Turner, "Revisiting Weber and Islam," ... 161-166.

19 Stephen Sharot, A Comparative Sociology of World Religions: Virtuosos, Priests, and Popular Religion (New York: New York University Press, 2001), 38.

20 Bryan S. Turner, For Weber: Essays on the Sociology of Fate (Boston: Routledge and Kegan Paul, 1981), 294. 
Abduh (1849-1905), and Rashid Rida (1865-1935). ${ }^{21}$ The Muslim reform movement was eager to return to the basic teachings of religion and create an ethical system free from mystical elements. Also, he thinks that Weber's theory of Protestant ethics fits the agenda of Islamic reform because "Islam accepts the Western view of how to realize capitalism by following the way of Protestant reform." ${ }^{22}$ The fact that alAfghani was nicknamed the 'Luther of Islam' is, according to Turner, proof that Protestant ethical teachings had "entered the heart' of the Islamic reform movement." ${ }^{23}$ However, Turner continues, "the Islamic version of Protestant ethics promoted by the reformers is nothing but junk" and proof that they had "plagiarized from the West." 24 Like Weber, Turner also believes that Islam does not have the capacity to bring about change and progress. If it does, then its ability stems from "the influence of the European culture that colonized them." ${ }^{25}$ Weber's greatest intellectual disciple and successor, Wolfgang Schluchter (1938-), inherited Weber's orientalist prejudice and further developed it. His assumption is no longer that 'Islam is incapable of developing' but a much more categorical 'Islam is a barrier to modernity.'

Moore describes Schluchter as the "most important contemporary European interpreter." ${ }^{26}$ In good Weberian tradition, he has authored an openly anti-Islamic article featured in a Weberian anthology. ${ }^{27}$ This collection celebrates Weber's success with his Protestant Ethics and reiterates the idea that Islam has failed to make a similar achievement. The authors, once again, affirm the Weberian premise of the 'patrimonial' and 'feudal' nature of Islam. Perhaps due to his negative view of Islam and apparent bias, Schluchter does not discuss Islam in his major work on rationalism, religion, and domination. ${ }^{28}$ This is particularly confounding since he seems knowledgeable enough to discuss Confucianism, Taoism, Hinduism, Buddhism, Christianity, and Judaism. He reveals the real reason for this omission in the preface. Upon stating that the intention of sociology of religion is to "compare and explain various views of the world" and "the lifestyle associated with those views", he concludes that:

"For this reason, the sociology of religion can be regarded as a large and comprehensive endeavor to understand modern Western culture, its ideas, and lifestyle. And in this way, the unique Western civilization which is a product of

21 Turner, Max Weber: From History to Modernity... 54-55.

22 Turner, Max Weber: From History to Modernity.... 54-55.

23 Turner, Max Weber: From History to Modernity.... 54-55.

24 Turner., Max Weber: From History to Modernity.... 54-55.

25 Turner., Max Weber: From History to Modernity.... 54-55.

26 K. Moore, "Paradoxes of Modernity: Culture and Conduct in the Theory of Max Weber. By Wolfgang Schluchter. Stanford University Press, 1996. 389 Pp. \$45.00," Social Forces 75, no. 4 (June 1, 1997): 1495, https://doi.org/10.1093/sf/75.4.1495.

27 Wolfgang Schluchter and Toby E. Huff, Max Weber and Islam (London and New York: Routledge, 1999).

28 Wolfgang Schluchter, Rationalism, Religion, and Domination, trans. Neil Solomon, (Los Angeles: University of California Press, 1989). 
Judaism and Christianity can be brought to the surface and then compare with other civilizations that are more or less created by other religions. ${ }^{29}$

\section{Sufism in the Eyes of the Weberians}

Among Weber's students and successors, Turner occupies a prominent position in the study of Islamic sociology. He was among the first to revisit Weber's thoughts on Islam. ${ }^{30}$ Regrettably, Turner's position on Weber and his portrayal of Islam is rather unpredictable. He tends to ascribe his own views to Weber, for instance, his views on the Prophet Muhammad as a prophet (even though Weber rejected it), shañ $` a$ as a holy law (even though Weber did not make this claim), and the Ash'arite concept of Adherents to the Sunnah and the Community (ahl al-sunnah wa-l-jamā'ah) as a distortion of the original concept of prophethood. However, Turner's analysis of Weber's views on Sufism seems plausible and justified, concluding that Weber's sociology of religion is essentially a discussion of personal piety. ${ }^{31}$

Personal piety is a manifestation of one's mystical experience and not the automatic result of one's religious affiliation. In other words, the notion of personal piety exists in all religions. In the context of Islam, Weber claimed that the Muslims' religious commitment results in patrimonialism, which is a militant attitude to fight, whereas spiritual awareness results in piety. Weber argued that religion can develop in two ways: through rational cognition and control over nature or mystical experience. ${ }^{32}$ Hence, every established religion comprises three elements: i) rational cognition, ii) mystical experience, and iii) religious practice. Rational cognition is a prerequisite without which religion cannot develop. The combination of all three elements are the characteristics of an advanced religion and in Weber's view only applies to the European religions (i.e., Christianity and Judaism). Mystical experience is necessary, but in the case of Islam, this second element has been replaced by worldliness and patrimonialism. The third characteristic, religious practice, is the most prominent element of Islam, as manifested in the strict adherence to the shant $a$ or Islamic law. However, according to Weber, Islamic law is irrational and devoid of intelligible principles. In consequence, Islamic religious law and practice are the most serious obstacle to the development of dynamic and efficient social and economic order.

This general framework, along with a series of theories on religion, is frequently used by Western sociologists, who cite him as an authoritative reference and use his ideas as a theoretical basis for their research on Islam and Sufism. In truth, however, Weber did not pay much attention to Islam or Sufism. One could argue that he did not know enough of Islam to have a legitimate opinion on it. Nevertheless, his general ideas on religion are deemed more than sufficient to serve as a solid theoretical

\footnotetext{
29 Schluchter and Huff, Max Weber and Islam.... Xv.

30 Bryan S. Turner, Weber and Islam (New York: Routledge, 1998).

31 Turner, "Revisiting Weber and Islam."...161-166.

32 Weber, Max Weber: Essays in Sociology... 282.
} 
foundation for studying any religion. As mentioned earlier, the best starting point for any study on Weber's thought on Islam is Turner's Weber and Islam. ${ }^{33}$ What has yet to be examined in more depth and detail are his views on Sufism. Although Weber discussed the spiritual dimension of Islam in only a few short paragraphs, many experts have explored Sufism using Weber's theoretical framework. When examining the work of those Western scholars of sociology who belong to the Weberian school, we find that they share the same Eurocentric viewpoint.

Eurocentrism means in this context that Western civilization is viewed as the sole source of civilizational progress and modernity. Weberian scholars believe that all civilizations except the Western civilization are bound to vanish in the course of time. The term used by Weber is disenchantment, which can be translated into disengagement of religion from human life. This pessimistic view is shared, for example, by Trimingham who predicts that Sufism would soon disappear. ${ }^{34}$ The two forces that would eliminate Sufism are modernization (external forces) and the Salafi/Wahabi movement (internal forces). ${ }^{35}$ Further, Trimingham argues that Sufism does not attract young followers, and is marginalized by secularist and Islamist ideology. ${ }^{36}$

Arberry shares a similar view but in a varied degree of emphasis. Where Trimingham adopts the thesis of 'the loss of Sufism', Arberry predicts the 'decline of Sufism.' Arberry, obviously inspired by Weber, distinguishes between what he calls 'mystical Sufism' and 'popular Sufism.' ${ }^{37}$ He understands Sufism as a model and ideal path taken to seek or find closeness to God. Slowly but surely, this mystical model turns into popular Sufism, as more and more people claim to be wat (Muslim saint) and demand loyalty and deference from their followers. Not a few of these alleged watis create their own cult to realize their self-serving aspirations and become the object of communal worship. Arberry then argues that "because of this shift and because Sufism has declined due to this change, it is then not attractive anymore." 38

Another figure who has adopted Weber's ideas and propagates similar ideas as Trimingham and Arberry is the American orientalist and anthropologist Michael Gilsenan (1940-). Like Trimingham, Gilsenan also focuses on the study of Sufism in Muslim Africa, in particular Egypt. ${ }^{39}$ He uses a Weberian framework when looking at the Muslim community in Egypt that he divides into 'scripturalists' and 'Sufis.' The scripturalists are represented by the jurists (Fuqaha') who represent the formal and

33 Turner, "Revisiting Weber and Islam,”... 161-166

34 J. Spencer Trimingham, The Sufi Orders in Islam (New York: Oxford University Press, 1971), 246.

35 Ron Geaves and Theodore Gabriel, Sufism in Britain (London: Bloomsbury, 2014), 56.

36 Martin van Bruinessen, "Sufism, Popular Islam and the Encounter with Modernity," in Islam and Modernity: Key Issues and Debates, ed. Muhammad Khalid Mas'ud, Armando Salvatore, and Martin van Bruinessen (Edinburgh: Edinburgh University Press, 2009), 125-57.

37 Nile Green, Sufism: A Global History(UK: Wiley-Blackwell, 2012), 1.

38 Green, Sufism: A Global History... 1.

39 Michael Gilsenan, Saint and Sufi in Modern Egypt (Oxford: Clarendon Press, 1973). 
systematic version of Islam, whereas the Sufis manifest their Islam in a charismatic manner. ${ }^{40}$ Like Trimingham and Arberry, Gilsenan agrees that the influence of Sufism has weakened over time, which he describes as a "decline of the social function of Sufism." Gilsenan further explains that the Egyptian Muslim community in general, whether represented by the 'ulama ' or the Sufis, has experienced the declining social function of Islam because of "the strengthening of the function of the state in all aspects of life." ${ }^{11}$ In other words, traditional Islam is powerless when faced with a secular and modern political infrastructure.

The Weberian discourse on Islam and Sufism in Europe is being continued by the British historian Mark Sedgwick. Like all Weberian scholars, especially Gilsenan, he agrees that the social role of the Sufis and the political role of the 'ulam $\bar{a}$ ' is diminishing due to the pervasive power of the secular state. ${ }^{42}$ On the other hand, he admits that Sufism can epistemologically dissolve into modern society. This is shown by "the change of Sufism from just a traditional spiritualism to a New Age Spirituality as practiced by Inayat Khan and Idris Shah." 43 This conclusion seems unreasonable, considering that Sufism and New Age spirituality are incommensurable in terms of their theology and epistemology; one carries a clear concept of God while the other does not. It becomes clear that Sedgwick understands Sufism in his own way. He sees the origin of Sufism not in Islam but in i) ancient Greek philosophy, especially the Neo-platonic school of emanation; ii) Judaism; and iii) Western esotericism through Spinoza and Helena Blavatsky ${ }^{44} \mathrm{He}$ thus understands Sufism as a universal phenomenon and a global, spiritual tradition rather than an Islamic one. Also, Sedgwick's discourse translates into a fusion of Sufism into modern spirituality and esotericism. It is turned from a specific religious form of spirituality into a universal, aesthetic spirituality. It is also no longer a home for seekers of God, but a mixed community of spiritual seekers, and thus far from organized religion. This approach of Sedgwick is in line with Weber's sociological orientalism. Among the other proponents of this idea of the decline and death of Sufism are Ira M. Lapidus, Arthur F. Buehler, Albrecht Hofheinz, Dale Eickelman, Cinvent Crapanzano, Clifford Geertz, and Ernest Gellner.

Lapidus argues that "Islam cannot develop into an institutionalized organization and capable of doing collective action" because Sufism is trapped in the cult of the individual (waî), closely followed by Buehler. Meanwhile, Hofheinz argues that

40 Ovamir Anjum, "Putting Islam Back into Equation: Islam as a Discursive World-System," in Islam and the Orientalist World-System, ed. Khaldoun Samman and Mazhar Al-Zo'by (USA: Routledge, 2008).

41 Mark Sedgwick, "Sufi Religious Leaders and Sufi Orders in the Contemporary Middle East," Sociology of Islam 6, no. 2 (2018): 212-32, https://doi.org/10.1163/22131418-00602007.

42 Sedgwick, "Sufi Religious Leaders and Sufi Orders in the Contemporary Middle East,"... 212-32.

43 Mark Sedgwick, Western Sufism: From the Abbasids to the New Age (Oxford: Oxford University Press, 2017), 1.

44 Sedgwick, Western Sufism: From the Abbasids to the New Age... 5. 
Sufism can only develop among illiterate people based on his research on the $19^{\text {th }}$ century Mahdi movement in Sudan. ${ }^{45}$ Eickelman takes a more moderate position by asserting that Sufism is inherently inflexible and static in nature because of the deep gulf that exists between idealism and social reality. ${ }^{46}$ Meanwhile, Crapanzano follows Freud's theory when studying the Hamadsha Sufi order (tañqa) in Morocco. He views Islam as "an expression of the innate feud between those who desire power," where the mainstream 'ulam $\bar{a}$ ' deliberately institutionalize these feuds to suit their interests. Sufis, on the other hand, are victims of the oppression of mainstream 'ulama'. Although methodologically a Freudian, Crapanzano is a Weberian in terms of his tendency to view Islamic society as "an entity that is constantly hostile to power." 47

Compared to other Weberians, Geertz and Gellner's views are more militant and bordering on the extreme. This is Cornell's opinion of Geertz, and Seesemann and Zubaidah's opinion of Gellner. ${ }^{48}$ Like Schluchter, Geertz and Gellner turn the notion of 'Sufism is difficult to develop' into 'Sufism is an obstacle to modernity.' Geertz warns that the Sufi watis are "the most accomplished con men who are good at moving the masses," ${ }^{49}$ while Gellner condemns Sufism, in a truly Marxian way, as 'the opium for society. ${ }^{50}$

\section{E. Counter Sociology}

In the area of Islamic sociology and Sufism, Weber remains a highly controversial figure. Weber's assumption regarding the 'exclusion of religion from society' has proven wrong and unfounded. On the contrary, religion, especially Islam has gained increasing momentum and continues to thrive, especially in the West. Bruinessen unequivocally rejects the Weberian claim that Sufism has been in the process of decline since the $19^{\text {th }}$ century. ${ }^{51}$ Instead, he argues that Sufism already started to re-emerge and flourish long before Weber was born, with the emergence of various Islamic reform movements in West Africa such as that of Shaikh Usman and Fodio in West Africa. ${ }^{52}$

However, the revival of Sufism did not only happen in West Africa. Geertz, Gellner, and Gilsenan focus their attention on modern Sufism in Morocco as the center of the most dynamic type of pre-modern and modern Sufism. Cornell does his own

45 See Dale F. Eickelman, "Muslim Publics," in Public Islam and the Common Good, ed. Armando Salvatore and Dale F. Eickelman (Leiden: Brill, 2006), 11.

46 Anjum, "Putting Islam Back into Equation: Islam as a Discursive World-System,"... 10.

47 Sumanto al-Qurtuby. "Islam, Muslim and Anthropoloy," International Journal of Islamic Thought 20, (2021): 138-155. https://doi.org/10.24035/ijit.20.2021.218 138.

48 Vincent J. Cornell, Realm of the Saint: Power and Authority in Moroccan Sufism (Texas: University of Texas Press, 1998), 28.

49 Cornell, Realm of the Saint: Power and Authority in Moroccan Sufism..., 28.

50 Rudiger Seesemann, The Divine Flood: Ibrahim Niasse and the Roots of a Twentieth-Century Sufi Revival (Oxford: Oxford University Press, 2011), 10.

51 Bruinessen, "Sufism, Popular Islam and the Encounter with Modernity".... 125-57.

52 Bruinessen, "Sufism, Popular Islam and the Encounter with Modernity".... 129. 
research in Morocco and finds to his surprise that Weber's most basic assumptions on the charismatic authority of the wat do not apply here. The core finding of Cornell's research is the concept of guardianship (wișāya), while Weberian scholars usually equate charisma with baraka (blessing) when discussing this concept. The authority of a guardian (wâși $)$ has not only charismatic but also ethical, doctrinal, social, legal, cultural, and political dimensions. ${ }^{53}$ In contrast, the original Weberian charisma theory only highlights the aspects of a leader's personality that attract his followers and bind them to him.

Cornell's study of the relationship between guardianship and power in Morocco, especially in the pre-modern era, further proves the dynamic nature of Sufism. Here, he focuses on the doctrinal problems in his mission to refute the ideas of Alfred Bel (1873-1945), who was a respected authority in Islamic studies on Morocco. Bel argued that Islam in North Africa, including Morocco, was established from the religious teachings of the Berbers who first occupied the region. The Berbers believed in good and evil as two opposing forces that continually compete for power. ${ }^{54}$ According to Bel, these teachings were later adopted by Islam and resulted in what he called 'the Arab ethos of Islam.' Within this framework, God is portrayed as a cruel God who has no mercy for his servants. This, according to Bel, is the background of the birth of the Sufism doctrines that are essentially intolerant, fatalistic, primitive, and backward. ${ }^{55}$ Cornell's criticism of Bel's views is quite substantial. He wants to prove that Islamic Sufism has succeeded in transforming the original doctrine of two competing forces into an egalitarian one, as evidenced in the dynamic relationship between the wat and the political ruler. According to Cornell, Bel's contribution was part of the colonialist political agenda to perpetuate colonialism and disenfranchise the Moroccan people.

Bel's work was continued by the political historian and anthropologist Ernest Gellner (1925-1995). Therefore, Cornell is bound to criticize him as well. Although Gellner has access to a plethora of information about Islam, he chooses to remain largely ignorant of it, which is a cause of great consternation for Cornell. He suspects that Gellner was a foreign imperial agent like Bel rather than a proper scholar. Gellner seemed to lack the basic ability to understand and appreciate foreign cultures and allowed Bel's flawed historical theory and Weber's interpretive sociology to lead him into the woods. Cornell finds it highly inappropriate for Gellner to equate the Islamic culture in modern Morocco with the Protestant culture in medieval Europe. ${ }^{56} \mathrm{He}$ remarks that Gellner's theories are hopelessly outdated and incompatible with the historical facts found on the ground. It becomes also clear that Gellner had never been

53 Cornell, Realm of the Saint: Power and Authority in Moroccan Sufism, 117. See also Rebecca Skreslet Hernandez, The Legal Thought of Jalāl Al-Dīn Al-Suyūțì: Authority and Legacy (Oxford: Oxford University Press, 2017), 11.

54 Cornell, Realm of the Saint: Power and Authority in Moroccan Sufism... 13.

55 Cornell, Realm of the Saint: Power and Authority in Moroccan Sufism... 14.

56 Cornell, Realm of the Saint: Power and Authority in Moroccan Sufism... 16.

Teosofia: Indonesian Journal of Islamic Mysticism, Vol. 9, No. 2, 2020 
serious in doing actual research in Morocco and instead preferred to spend his time overseas sightseeing and hiking. Cornell concludes that most of Gellner's scholarly output is a rehash of second-hand sources rather than original and independent research.

Another center of attention among the Weberian orientalists is Egypt. As discussed earlier, Weber's thesis of the decline of Sufism has disproved itself and is not taken up again by his successors like Gilsenan. He proposes that in Egypt, Sufism, and Islam, in general, have lost their social influence. Their social functions have been taken over by the state through educational, political, and economic institutions. Surprisingly, his study of the Hamidi-Shadhuli Sufi order shows that it has managed to survive and even flourish amid the numerous challenges that are confronting it "because it can transform into a modern formal organization." 57

Similar studies have produced the same findings, namely that the Sufi orders were, contrary to expectation, able to accommodate modernity and development. First, Pritchard's study of the Sanusi order in the Badawi Cyrenaica tribe showed the success of the Sufi order in pacifying and reconciling the local communities. ${ }^{58}$ In Libya, the Sufi order succeeded in rallying the local population in their resistance against the Italian occupation (1911-1943). After gaining independence in 1951, the first monarch of the Kingdom of Libya, Idris I, was a murshīd (spiritual mentor) in the Sanusi order. Another study on the struggle of the Naqshbandi order in the Caucasus and North Kurdistan against the Russian occupation (1800-1864) and the murder of their leader Shamil in 1859. ${ }^{59}$ Third, Anatolian cities like Bursa, Kayseri, and Konya in Turkey experienced rapid economic growth, while its communities retained and even strengthened their religious and spiritual identity. These so-called 'Anatolian Tigers' were also referred to as 'Islamic Calvinists' because of their intense personal piety. ${ }^{60} \mathrm{~A}$ fourth study found that Turkish and Muslim managers achieved the highest score in terms of work ethic compared to their British and Protestant, or Irish and Catholic counterparts. $^{61}$

No less important is the role of Sufi orders in the political sphere. Bruinessen's research revealed the active involvement of the Sammani, the Qadiri, and the Naqshbandi orders in the national struggle for independence. In the context of Indonesia, the Sufi orders were also directly involved in the struggle against Dutch and

57 Bruinessen, "Sufism, Popular Islam and the Encounter with Modernity"... 125-57.

58 Evans-Pritchard, Edward Evan. The Sanusi of Cyrenaica. At the Clarendon Press, 1949, https://ehrafworldcultures.yale.edu/document?id=mt09-003.

59 Michael Reynolds, "Myths and Mysticism: A Longitudinal Perspective on Islam and Conflict in the North Caucasus." Middle Eastern Studies 41, no. 1 (2005): 31-54. http://www.jstor.org/stable/4284344.

60 Ömer Demir, Mustafa Acar, and Metin Toprak, "Anatolian Tigers or Islamic Capital: Prospects and Challenges," Middle Eastern Studies 40, no. 6 (November 8, 2004): 166-88, https://doi.org/10.1080/0026320042000282937.

${ }_{61}$ M. Arslan, "The Work Ethic Values of Protestant British, Catholic Irish and Muslim Turkish Managers," Journal of Business Ethics 31 (2001): 321-39, https://doi.org/https://doi.org/10.1023/A:1010787528465. 
English colonizers. For instance, the head of the Khalwatiyah Tariqa, Yusuf alMakassari (1626-1699) received a posthumous award from President Soeharto in 1995 and the same title from the South African President, Thabo Mbeki, in 2009 (Sheikh Yusuf was permanently exiled to the Cape of Good Hope in 1693 where he died in 1699). His legendary struggle against colonialism is a well-known part of Indonesian history. Further, the Malaysian scholar Syed Hussein Alatas observes that the early European colonial powers were aware of the social role of the Sufi orders in Muslim society and their economic significance. In the early $20^{\text {th }}$ cent ury, colonial officer Kock wrote a report to the Dutch East India Company directors in which he described the religious and economic conditions in Java. He stated that Sarekat Islam had a large community of followers and dominated the economic sector. Interestingly, Kock compared the emergence of this local capitalist class with the emergence of Protestant capitalists in Europe in the early $16^{\text {th }}$ century. He saw the change in the economic behavior and the transition from a traditional to a semi-modern structure reflected in the emergence of small industries in Java. According to Kock, this was "in line with the teachings of modern economics by Luther and Calvin."62

The modern development of Sufism in the national context has also attracted the attention of historians and anthropologists. Bennet and Alam have published a comprehensive study on Sufism, pluralism, and democracy. ${ }^{63}$ It traces the involvement of Sufi orders in the world of practical politics in several Islamic countries including Indonesia, Egypt, Bangladesh, and Turkey. The basic premise is that the Sufi orders play a major role in supporting the democratic culture of their community. In opposition to radicalism, the Sufi orders also stand up against political oppression and authoritarian rule. ${ }^{64}$ The Australian scholar Milad Milani has carried out a study on Sufism in Indonesia. He agrees that Sufism is not a local phenomenon; rather, it became a transnational movement long before the emergence of the concept of the nation-state. Surprisingly, Sufism can counter the global standardization of religion. ${ }^{65}$ It neutralizes the concept of religious violence echoed by global powers. Sufism and taniqas are no longer regarded as the last remnants of traditional village life. The recent emergence of Sufi orders in the West has also shown that religious spirituality is welcomed in modern society, especially in decidedly secular countries. This might be partially due to the spiritual drought experienced by modern humanity, but even more so because of the ability of Sufism to adapt and accommodate.

62 Syed Hussein Alatas, "The Weber Thesis and South East Asia," Archives de Sciences Sociales Des Religions 15, no. 1 (1963): 21-34, https://doi.org/10.3406/assr.1963.1719.

63 Clinton Bennett and Sarwar Alam, Sufism, Pluralism and Democracy (England: Equinox, 2017).

64 Bennett and Alam, Sufism, Pluralism and Democracy... 9.

65 Milad Milani, Adam Possamai, and Firdaus Wajdi, "Branding of Spiritual Authenticity and Nationalism in Transnational Sufism," in Religions, Nations, and Transnationalism in Multiple Modernities, ed. Patrick Michel, Adam Possamai, and Bryan S. Turner (New York: Palgrave Macmillan, 2017), 197.

Teosofia: Indonesian Journal of Islamic Mysticism, Vol. 9, No. 2, 2020 
This evident spirit of resilience amid adversity becomes clear in Europe, where Muslims are a minority and Islam is still a largely unrecognized religion. Ironically, it was here, in Western Europe, the heartland of the Weberian school, where the original theory of the supposed 'decline of Sufism' emerged and the effort to mainstream the discourse of 'modernity rejecting religion' was begun. Today, however, it seems that the opposite is happening; religion, especially Islam, has slowly but surely become a force to be reckoned with. More and more scholars who study Islam and Sufism voice their dismay at Weber's apparent inability to arrive at an objective view of Islam and Sufism, particularly in Europe and the United States. The recent work by Malik and Zarrabi-Zade examines the successful global phenomenon of Sufism today. ${ }^{66}$ This study adopts the premise that Sufism is directly involved in the process of cultural exchange between Islam and modern Western society. Furthermore, this involvement has been ongoing for the last two and a half centuries and began at a time when the concept of modernity was only just emerging. Thus, Sufism preceded modernity in terms of initiating a cultural exchange discourse. In other words, Sufism is more modern than modernity itself.

In 2017, Knysh has published another comprehensive study on Islamic mysticism which does away with many of Weber's outdated ideas. ${ }^{67}$ Although his topical survey does not really contain a 'new history' as suggested in the title, ${ }^{68}$ Knysh nevertheless offers some interesting findings. The tasawwuf (Sufism) movement represents, he concludes, "the silent rebellion of the Sufis." 69 It entails the quiet opposition against anything and anyone who stands against the prevailing moral order and social values. Further, its dynamic nature causes it always to move forward and 'make history' rather than observe it passively. According to the Sufi understanding, history is made for the benefit of the people by offering sound values and systems. The fact that Sufism can keep moving with the system and its norms is proof of its dynamic nature. In other words, those who view Sufism as a thing of the past are bound to be disappointed because "Sufism is not the past but the present."

Knysh's determination to refute Weber's immature and biased ideas on Sufism is obvious as well as understandable. His open and direct critique of Weber commences in the first line of his introduction and does not stop there. He disagrees with the standard Weberian distinction between mysticism and asceticism ${ }^{71}$ that makes any

${ }^{66}$ Jamal Malik and Saeed Zarrabi-Zadeh, "Introduction," in Sufism East and West (Leiden: BRILL, 2019), 1, https://doi.org/10.1163/9789004393929_002.

${ }^{67}$ Alexander Knysh, Sufism: A New History of Islamic Mysticism (New Jersey: Princeton University Press, 2017).

${ }^{68}$ Knysh was not too sure about the title of the book. He wrote, "Whether the title of this book matches its content, I leave it to the reader to judge it". Knysh, Sufism: A New History of Islamic Mysticism, 10.

${ }^{69}$ Knysh, Sufism: A New History of Islamic Mysticism... 10.

70 Knysh, Sufism: A New History of Islamic Mysticism... 2.

71 Knysh, Sufism: A New History of Islamic Mysticism... 1. 
attempt to understand Sufism very doubtful and prone to failure. Methodologically, this separation would corrupt the correct understanding of Sufism and misrepresent it as a movement that wishes to withdraw from the world, disengaged and passive. Weber himself viewed Sufism in the monastic and ascetic sense of renouncing all worldly pleasures, refusing to work and earn a living, and accepting alms, claiming sanctity, and in return extending blessings' and performing miracles. Salvatore's study on Islamic sociology was published only a few years before Knysh makes a similar point. It places Weber firmly in the ranks of Western orientalists whose sole mission in life is to prove that "only Western society is rational and could be modern."72

Salvatore's positive attitude towards Sufism stands out, and his research suggests that he is impressed by the development of Sufism, as evidenced in recent history. In the context of Britain, the negative stigma affixed to religion has caused the near-complete disappearance of religious spirituality and mysticism from public life. However, while Christian spirituality is slowly fading away, Islam and Islamic spirituality are steadily on the rise. This phenomenon of gaining popularity of Sufism amid the decline of Western religion does indeed defy all expectations. This observation has been made first by Geaves and Gabriel and seems to have found resonance in the sociological circles. According to Geaves, the signs of the emergence of Sufism as an alternative social force have already emerged in the 1960s. Since then, Sufism has played an important role in offering a 'counterculture spirituality'. ${ }^{73}$ Starting from the 1990s, Sufism has launched itself as a "global movement that transcends the boundaries of locality and ethnicity" ${ }^{74}$

Gabriel and Greaves' first comprehensive work on Sufism in Britain has revived the interest in this area of research and initiated a new debate. It suggests that in the beginning Sufism in the West was synonymous with certain ethnic groups, especially immigrants from South Asia, the majority coming from India and Pakistan. ${ }^{75}$ In the context of economic migration in the $20^{\text {th }}$ century, Sufism helped the socially displaced and isolated immigrants to maintain their cultural and religious identity. Subsequently, Greaves has co-authored another study with Dressler and Klinkhammer in which he modifies his earlier conclusion based on more recent developments. He confirms that Sufism has become a "world-class spiritual capital with a global network" and rejects the negative stigma attached to Sufism and adopts a more nuanced and objective understanding of the phenomenon. Weber's original assumption that Sufism is a highly conservative form of 'collective fanaticism' or Tholuck's idea

72 Armando Salvatore, The Sociology of Islam: Knowledge, Power and Civility... 2.

73 Ron Geaves and Theodore Gabriel, "Sufism in Britain", Journal of Qur'anic Studies 17, no. 1, (2013): 2. https://www.euppublishing.com/doi/abs/10.3366/jqs.2015.0182.

74 Geaves and Gabriel, "Sufism in Britain,"... 5.

75 Geaves and Gabriel, "Sufism in Britain,"... 3. 
that Sufism is a "primitive spirituality that has no purpose" from being conservative, fanatical, and primitive, Geaves observes that Sufism is indeed a very dynamic, tolerant, and sophisticated social movement. He writes:

"Sufism is not affected by changes caused by modernity or urban lifestyles.

Sufism serves as a mechanism to promote mysticism not only for the internal Muslims but also for European nations who are looking for spirituality. Also, it is a mechanism for transmitting religious culture into a new context in Europe." 77

Several studies conducted by other historians and anthropologists support this finding. At least two studies deserve to be mentioned briefly. Raudvere and Stenberg completed a study on Sufism in Britain, Canada, the United States, Brazil, and several Muslim countries. ${ }^{78}$ It reveals that Sufism has become the object of serious debate and study, with particular attention to the development of organizational networks, political agendas, and new rituals. The study looks beyond Sufism at the regional and national level and includes its role as a transnational and international movement. The themes include: i) politics of Sufism, ii) restructuring Sufi orders in Turkey, iii) cultural creativity in Sufi orders in Syria, iv) creating a globalized Sufi network, v) transplanting Sufism to the United States, vi) emerging Sufism in Britain and Sweden. The study found that Sufism seems to be very attractive to young people, especially women because it allows them to reconcile spirituality with modernity. The authors conclude that "Sufism, theology, and its traditions have undergone adaptations in the latter half of the modern century". 79

The second study by Werbner also examines the phenomenon of global Sufism today. ${ }^{80}$ She found that the Naqshbandi order has been able to successfully adapt and evolve over time. This tañ $q$ a was founded in a remote village in Pakistan in the $14^{\text {th }}$ century but has since then grown into a thriving global community, spreading from Southeast Asia to the Middle East, South Africa, Europe, and the United States. Werbner portrays modern Sufism as i) a late-capitalist, post-colonial, and spiritual movement, ii) a transnational religious movement, and iii) a movement for the globalization of religion. ${ }^{81}$

76 Markus Dressler, Ron Geaves, and Gritt Klinkhammer, "Introduction," in Sufis in Western Society: Global Networking and Locality (USA: Routledge, 2009), 1. Friedrich August Gottreu Tholuck (1799-1807) was a German Protestant theologian, historian, and church leader.

77 Geaves and Gabriel, "Sufism in Britain,"... 3.

78 Catharina Raudvere and Leif Stenberg, Sufism Today: Heritage and Tradition in the Global Community (London: IB Tauris, 2009).

79 Raudvere and Stenberg, Sufism Today: Heritage and Tradition in the Global Community... 1-12.

80 Pnina Werbner, Pilgrims of Love: The Anthropology of a Global Sufi Cult (London: Hurst and Company, 2003).

81 Werbner, Pilgrims of Love: The Anthropology of a Global Sufi Cult... 1. 


\section{F. Conclusion}

Weber's sociological theory has helped many scholars to study the phenomenon of religion. Debates over the issues of modernity and secularization are always, in some form or another, connected with the Weberian discourse. Some even go as far as saying that the notion of modernity is the very essence of Weber's sociology. However, like many Western anthropologists of the past, Weber grossly underestimated Islam and was in fact largely ignorant of it. This kind of intellectual and cultural prejudice has delayed the development of a comprehensive theory of Islamic sociology and produced a whole generation of Western sociologists and anthropologists who were equally dismissive of the role of Islam and Sufism. The sociology of Islam, especially the sociology of Sufism, remains a highly underrepresented area of research. In addition, the dependence of Muslim scholars on the Western discourse has robbed this science of its focus and slowed its development. For too long it has been based on a theoretical framework that does not reflect the actual conditions of Muslim society. Islamic sociology thus has yet to resolve two major issues: religious authority and religious identity. If these two issues are not resolved, the development of this science will soon cease to be relevant.

Unlike Western sociology, which has Weber and his intellectual successors as authoritative references, the sociology of Islam has not yet produced such acknowledged experts and authorities. This, in turn, affects the identity and authenticity of this young science. Today, the sociology of Islam and the sociology of Sufism are still very much dependent on the framework established by Western scholars. Sociology of Islam and Sufism are still developing at the level of "responding to crises and anomalies," to borrow Kuhn's phrase. In the near future, it may develop into a regular science and ultimately a new paradigm. Weber's controversial thesis followed by its anti-thesis and final synthesis has become important assets in developing Islamic sociology and Sufism. The aim of this study is not to refute or discredit the legacy of Weber's thought. Science is a continuing process, and Weber's successors have contributed much to correct, improve, and expand upon his original ideas. Likewise, the critics and opponents of Weberian theory have enriched and redirected the sociological discourse on Sufism.

The portrayal of Sufism in the sociological study is decided by examining its varied aspects. If positioned as a social phenomenon, Sufism offers a rich treasury of material to be interpreted. Sociology is an attempt to find meaning, and Sufism has abundant meaning to reveal. Likewise, sociologists like to discover and read hidden meanings. In this regard, sociological theory can provide a very helpful underpinning to the study of Sufism. Equally, sociology can learn much from Sufism. In this era of continuous change and loss of identity, Sufism has remained a permanent fixture and has never lost its identity. In Werbner's words, "space is deterritorialized and reterritorialized" meaning that Sufism can appropriate a new space and then restore 
itself and assume its original condition. When Sufism enters an area, it blends into the new identity, infuses itself with it, and re-establishes itself in the new environment. Sufism never loses its religious identity and spirituality, can cross over boundaries, withstand the tide of secularism and materialism, and unify society, no matter how disparate its elements.

\section{Bibliography}

Alatas, Syed Farid. "The Weber Thesis and South East Asia." Archives de Sciences Sociales Des Religions 15, no. 1 (1963): 21-34. https://doi.org/10.3406/assr.1963.1719.

Anjum, Ovamir. "Putting Islam Back into Equation: Islam as a Discursive WorldSystem." In Islam and the Orientalist World-System, edited by Khaldoun Samman and Mazhar Al-Zo'by. USA: Routledge, 2008.

Arslan, M. "The Work Ethic Values of Protestant British, Catholic Irish and Muslim Turkish Managers." Journal of Business Ethics 31 (2001): 321-339. https://doi.org/https://doi.org/10.1023/A:1010787528465.

Bennett, Clinton, and Sarwar Alam. Sufism, Pluralism, and Democracy. England: Equinox, 2017.

Berger, Peter L. "Charisma and Religious Innovation: The Social Location of Israelite Prophecy." American Sociological Review 28, no. 6 (December 1963): 940. https://doi.org/10.2307/2090313.

Bilqies, Shahida. "Understanding the Concept of Islamic Sufism." Journal of Education \& Social Policy 1, no. 1 (2014): 55-72. http://jespnet.com/journal/index/2130.

Bruinessen, Martin van. "Sufism, Popular Islam and the Encounter with Modernity." In Islam and Modernity: Key Issues and Debates, edited by Muhammad Khalid Mas'ud, Armando Salvatore, and Martin van Bruinessen. Edinburgh: Edinburgh University Press, 2009.

Cornell, Vincent J. Realm of the Saint: Power and Authority in Moroccan Sufism. Texas: University of Texas Press, 1998.

Demir, Ömer, Mustafa Acar, and Metin Toprak. "Anatolian Tigers or Islamic Capital: Prospects and Challenges." Middle Eastern Studies 40, no. 6 (November 8, 2004): 166-88. https://doi.org/10.1080/0026320042000282937.

Dressler, Markus, Ron Geaves, and Gritt Klinkhammer. "Introduction." In Sufis in 
Western Society: Global Networking and Locality. USA: Routledge, 2009.

Eickelman, Dale F. "Muslim Publics." In Public Islam and the Common Good, edited by Armando Salvatore and Dale F. Eickelman. Leiden: Brill, 2006.

Encyclopedia.com. "“Functionalism and Structuralism' Encyclopedia of Sociology," February 7, 2021. https://www.encyclopedia.com/social-sciences/encyclopediasalmanacs-transcripts-and-maps/functionalism-and-structuralism.

Evans-Pritchard \& Edward Evan. The Sanusi of Cyrenaica. At the Clarendon Press, 1949, https://ehrafworldcultures.yale.edu/document?id=mt09-003.

Geaves, Ron, and Theodore Gabriel. Sufism in Britain. London: Bloomsbury, 2014.

Green, Nile. Sufism: A Global History. UK: Wiley-Blackwell, 2012.

Hernandez, Rebecca Skreslet. The Legal Thought of Jalāl Al-Dīn Al-Suyūți: Authority and Legacy. Oxford: Oxford University Press, 2017.

Knysh, Alexander. Sufism: A New History of Islamic Mysticism. New Jersey: Princeton University Press, 2017.

Malik, Jamal, and Saeed Zarrabi-Zadeh. "Introduction." In Sufism East and West. Leiden: BRILL, 2019. https://doi.org/10.1163/9789004393929_002.

Milani, Milad, Adam Possamai, and Firdaus Wajdi. "Branding of Spiritual Authenticity and Nationalism in Transnational Sufism." In Religions, Nations, and Transnationalism in Multiple Modernities, edited by Patrick Michel, Adam Possamai, and Bryan S. Turner. New York: Palgrave Macmillan, 2017.

Moore, K. "Paradoxes of Modernity: Culture and Conduct in the Theory of Max Weber. By Wolfgang Schluchter. Stanford University Press, 1996. 389 Pp. \$45.00." Social Forces 75, no. 4 (June 1, 1997): 1495-96. https://doi.org/10.1093/sf/75.4.1495.

al-Qurtuby, Sumanto. "Islam, Muslim, and Anthropology," International Journal of Islamic Thought 20, (2021): 138-155. https://doi.org/10.24035/ijit.20.2021.218 138

Raudvere, Catharina, and Leif Stenberg. Sufism Today: Heritage and Tradition in the Global Community. London: IB Tauris, 2009.

Reynolds, Michael. "Myths and Mysticism: A Longitudinal Perspective on Islam and Conflict in the North Caucasus." Middle Eastern Studies 41, no. 1 (2005): 31-54. http://www.jstor.org/stable/4284344.

Runciman, W. G. "The Sociological Explanation of 'Religious' Beliefs." European Journal of Sociology 10, no. 2 (November 28, 1969): 149-91. https://doi.org/10.1017/S0003975600001806.

Salvatore, Armando. The Sociology of Islam: Knowledge, Power, and Civility. USA:

Teosofia: Indonesian Journal of Islamic Mysticism, Vol. 9, No. 2, 2020 
Wiley-Blackwell, 2016.

Schluchter, Wolfgang, and Toby E. Huff. Max Weber and Islam. London and New York: Routledge, 1999.

Sedgwick, Mark. "Sufi Religious Leaders and Sufi Orders in the Contemporary Middle East." Sociology of Islam 6, no. 2 (June 6, 2018): 212-32. https://doi.org/10.1163/22131418-00602007.

- Western Sufism: From the Abbasids to the New Age. Oxford: Oxford University Press, 2017.

Seesemann, Rudiger. The Divine Flood: Ibrahim Niasse and the Roots of a TwentiethCentury Sufi Revival. Oxford: Oxford University Press, 2011.

Sharot, Stephen. A Comparative Sociology of World Religions: Virtuosos, Priests, and Popular Religion. New York: New York University Press, 2001.

Soyer, Mehmet. "Examining the Origins of Sociology: Continuities and Divergences Between Ibn Khaldun, Giambattista Vico, August Comte, Ludwig Gumplowicz, and Emile Durkheim." University of North Texas, 2010.

Turner, Bryan S. For Weber: Essays on the Sociology of Fate. Boston: Routledge and Kegan Paul, 1981.

—. Max Weber: From History to Modernity. London: Routledge, 1992.

- "Revisiting Weber and Islam." The British Journal of Sociology 61, no. 1 (January 14, 2010): 161-66. https://doi.org/10.1111/j.1468-4446.2009.01285.x.

Weber, Max. From Max Weber: Essays in Sociology. Edited by Hans Heinrich Gerth and Charles Wright Mills. United Kingdom: Routledge, 1991.

Wirtschaft und Gesellschaft - Grundriß der verstehenden Soziologie. Tübingen: Mohr, 1980.

Werbner, Pnina. Pilgrims of Love: The Anthropology of a Global Sufi Cult. London: Hurst and Company, 2003. 